\title{
THE CLASSIFICATION OF SOURCES OF REPRODUCTION OF SHADOW RELATIONS IN THE SPHERE OF PRODUCTION AND REALIZATION OF HOUSING AND COMMUNAL SERVICES
}

\author{
Iryna Chekhovska', Natalia Nykytchenko², Tetiana Bilous ${ }^{3}$
}

\begin{abstract}
The purpose of this article is to analyse the sources of shadow relations in the sphere of production and realization of housing and communal services (technologies and causes of their occurrence, subjects' complex, level of danger, etc.); the classification of these sources of shadow relations, the definition of priorities in the development of state measures on the localization of certain sources of shadow relations in the field of production and implementation of housing and communal services, depending on the trend of their development, the level of danger to society. Methodology. The methodological foundations of research the sources of shadow relations in the field of production and realization of housing and communal services are determined by a set of methods of scientific knowledge, which allow considering the studied topics as a multidimensional, interdisciplinary phenomenon. In the course of scientific research, the following methods were used: scientific abstraction and systemic were used to generalize the current state of the production and realization of housing and communal services, to define a system of administrative measures in order to distinguish its shadow aspects; systematic structural and formaldogmatic methods allowed exploring and classifying the sources of shadow relations; formal-legal was used to study the regulatory framework governing the relations in the field of study. The paper also uses methods of statistical, comparative analysis, dialectic, extrapolation, etc. Results. The classification of sources of shadow relations will allow monitoring of financial and economic capital and document circulation in the sphere of production and realization of housing and communal services in order to determine the whole spectrum of sources of shadow relations from socially neutral, socially positive, socially-changing (disappearing) sources of the informal sector shadow economy, to socially-variable (newly created), socially negative and antisocial sources of the underground sector of the shadow economy. The isolation of the most dangerous sources of shadow relations, producing a significant illegal potential in the field of production and implementation of housing and communal services will enable the development of a causal rather than a consequential problem and a way to combat the most dangerous acts that are reproducing-progressing sources of the shadow economy in this area of research.
\end{abstract}

Key words: shadow economy, shadow relations, sources of shadow relations, housing and communal services.

JEL Classification: 017,018

\section{Introduction}

As a public phenomenon, the "shadow economy" is inherent in all countries regardless of the model and level of their socio-economic development. However, in domestic and foreign literature, there is no generally accepted definition of this phenomenon, which scientists and practitioners called "shadow economy". First of all, attention is drawn to the existing variety of terms used to define the concept of "shadow economic activity". From the western literature to our domestic use, a lot of them were used: shadow economy, informal

\footnotetext{
Corresponding author:

${ }^{1}$ National University of State Fiscal Service of Ukraine, Ukraine.

E-mail: kontanta08@ukr.net

${ }^{2}$ National University of State Fiscal Service of Ukraine, Ukraine.

E-mail: revyuk@ukr.net

${ }^{3}$ National University of State Fiscal Service of Ukraine, Ukraine.

E-mail: tanyshabilous@gmail.com
}

economy, hidden economy, non-official economy, secondary economy, black economy, secret economy, underground economy, illegal economy, black market, etc. (Mandybura, 2001).

Such a numerical set of terms is not accidental and reflects not only the lack of unity to the conceptual understanding of this phenomenon but the various aspects and structural components of the "shadow economy" and also emphasizes the internal qualitative complexity of this phenomenon. It was studied by domestic and foreign scholars such as G. Becker, 
A. Baseluk, O. Bandurka, V. Blades, Z. Varnalius, V. Heiets, D. Gershuni, P. Gutman, J. Zhalilo, N. Kauffmann, F. Keygan, T. Korjagina, I. Mazur, N. Matzievsky, V. Mamutov, O. Mandybura, G. Myrdal, I. Puzanov, V. Popovych, V. Rutgaiser, K. Svenson, O. Tylchyk, O. Turchynov, I. Turkevych, O. Hihins, E. Feig, H. Hermann, K. Hart, A. Shokhin, and others.

So, among Ukrainian scholarly publications on the problems of shadowing of the economy, the views on shadow processes in Ukraine are most fully reflected in the work of O.V. Turchynova "Shadow economy: theoretical foundations of research" (Turchynov, 1995). The author distinguishes four components of the shadow economy:

- unconcealed from state bodies the economic activity, but because of objective and subjective reasons are not taken into account, uncontrollable and tax exempt by the state;

- legal economic activities in the process of which there is a complete or partial evasion of taxes, fees, fines and other mandatory payments, as well as violations of its state regulation (the subject of shadow economic activity receives additional income by violating the current tax and other legislation, which regulates economic activity);

- illegal economic activity deliberately concealed from the state bodies;

- the activity aimed at obtaining income by committing or facilitating the commission of crimes which entail criminal responsibility.

According to Turchynov's definition, the shadow economy is an economic activity that is not taken into account, is not controlled and is not taxed by the state and (or) aimed at obtaining income by violating the current legislation (Turchynov, 1995).

A more detailed analysis of the basic provisions on the definition of the concept, structure, and methods of assessing the shadow economy is given in the writings of Ukrainian scientists, presented in his monograph (Popovych, 2001). In the opinion of the researcher, the definition of the concept of "shadow economy" is repeated in one or another interpretation in the works of most scholars, but it only reflects the upper, general cut of the shadow economy, is not sufficient for the objective representation of the technological structure of the object, subjective and causal composition of the shadow relationships. In his work, the scientist gives his own definition of the concept of "shadow economy". Thus, the shadow economy is a collection of socially-neutral or socially-positive, non-taxable sources of income of citizens received from unreported and non-taxable state types of economic activity, as well as a conglomeration of socially-negative sources of shadow revenues and anti-social sources of shadow capital received through the commission of unlawful but non-criminal shadow acts in those or other segments of socio-economic, financial, civil-legal relations or relations in the field of civil circulation of things, rights, actions of the country as a whole (Turchynov, 1995). Therefore, sources of shadow revenues as elements of the shadow economy component may be any segment of relations that constitutes the movement of goods, rights, actions in the field of civilian turnover of the country.

According to the same author, the constituent elements of the shadow economy are the sources, types, and subspecies of sources of the shadow economy.

The sources of the shadow economy by logicalstructural form are the constituent elements of a particular shadow economy sector. According to the content, this is a hand-crafted production economic activity, not taken into account by the state for reasons of exemption from taxes, occasional, insignificant volumes of service income in the "informal sector" of the shadow economy, as well as sources of the "underground sector". Shadow economy - socially negative and antisocial criminalized or non-criminalized acts, illegal or pseudo-legal financial-economic or civil-law operations aimed at the accumulation, reproduction, laundering or legalization of capital illegal origin in the civil circulation of things, rights, actions.

Thus, in the form and content, the source of the shadow economy V. Popovych divides into two types: the sources of the informal and the source of the underground sectors of the shadow economy, as to the structure the author singles out - on the various levels, diverse species or subspecies of sources.

Taking advantage of the theory of the shadowing of the economy by the classifier-matrix of species, subspecies of multilevel, single-profile, and diverse sources of the underground sector of the shadow economy and the general structure of the constituent elements of the shadow economy, Yu. Groshovyk and N. Drugval conducted an investigation of sources of shadow relations in the field of the circulation of intellectual property objects (Groshovyk, 2003) and in the field of foreign economic activity (Drugval, 2004) through the developed conceptual apparatus. The experiments developed by these researchers allowed them to more fully define, on the productive systemmethodological level, the existing "single-profile", "diversified" and "multi-level" sources of shadowing of social and economic relations in the sphere of production and realization of housing and communal services; to predict the origin of those sources that for certain reasons may appear in the future and to realize the technology and the causal composition of the occurrence of certain sources of shadow economy, their subject complexes, the level of danger, the power of each of these sources or their structural segments, and set priorities in the development of state measures to localize certain sources of shadow relations in the field of production and implementation of housing and communal services, depending on the tendency of their development, the level of danger to society. This, in turn, 
will allow for the development of a causal rather than a consequent problem and a way of combating the most dangerous acts that are reproductive and progressive sources of the shadow economy in this area of research, which, unfortunately (and this will be shown below), is not given proper attention warning.

\section{Characteristics of the current state of the sphere of production and realization of housing and communal services in Ukraine}

To characterize the current state of affairs, it is enough to give concrete facts. According to the results of work in 2016, losses of housing and communal services enterprises of Ukraine amounted to 5.4 billion hryvnias. Of this amount, the losses of district heating company were 4.1 billion hryvnias. At the same time, debtor indebtedness amounted to 13.3 billion hryvnias in 2016, accounts due from customers 28.0 billion hryvnias (news online, 2018). In 2017, the losses of housing and communal services enterprises of Ukraine already amounted to 6.1 billion hryvnias, respectively, the debt of district heating company went up to 4.3 billion hryvnias, while the indebtedness of the population for consumed housing and communal services amounted to 5.7 billion hryvnias (a briefing note, 2018). As a consequence, there is an inadequate level of technical state of the industry: the share of district heating companies (almost 25\%), water supply networks (almost 40\%), sewage networks (almost 41\%) has considerably increased; nearly twice the loss of thermal energy has increased, water losses have exceeded 50\% of the total volume allowed to consumers. Due to unsatisfactory sanitary and technical condition of water supply and sewage facilities and networks, the quality of drinking water deteriorated. Thus, monitoring of water quality in surface water bodies used as sources of centralized water supply of the population showed that the proportion of investigated water samples that did not meet the sanitary and bacteriological standards in 2017 increased by 5\% compared to 2015 and amounted to almost a quarter to verified. Consequently, the use of poor-quality drinking water caused an increase in infectious diseases in the population (auditor services site, 2018).

It should be noted that heat supply in the centralized system during the heating period is served at minimum parameters or switched off at all, the schedule of the beginning and end of the heating season is violated. In a number of cities, there is no centralized hot water supply at all.

The list can be continued, but it is already enough to conclude that the housing and communal sector is in critical condition. The reason for this is to a large extent the shadow manifestations.

The above mentioned points to the urgent need for targeted and systematic measures aimed at reducing the economic relations in the sphere of production and realization of housing and communal services: for consideration and analysis not only of the governing bodies directly implementing the state policy in this sphere, but also bodies of public administration, creation of favourable economic, organizational and legal conditions for the transfer of shadow economic activity to the legal side. But to do this without defining a concept that would help to identify the sources and methods of organized manifestations of the shadow economy in the area of housing and communal services will be impossible.

It is necessary to develop such a concept on the basis of extrapolation of concepts and methodologies developed in the general part of "The theory of unshadowing economy" (Popovych, 2001). At the same time, it is necessary to take into account the specifics of the relations that have developed in the field of production and implementation of housing and communal services.

Thus, shadow relations in the sphere of production and realization of housing and communal services are state-management, economic, and legal relations that arise as a result of deviant behaviour of the subjects of production and sale of housing and communal services or officials of the state, public administration and local self-government in the performance of regulatory, registration, licensing and control functions.

Taking into account the notion of shadow relations in the sphere of production and realization of housing and communal services, it can be concluded that due to its social nature and the level of social danger, the sources of shadow manifestations in the sphere of housing and communal services are socially variable, newly formed socio-negative and antisocial sources of the underground sector of the shadow economy.

Based on a certain notion, we classify the main groups of sources of shadow relations that take place in the field of production and sale of housing and communal services on the following grounds: a group of sources of shadow relations in the field of production and implementation of housing and communal services of a state-management nature; a group of sources of shadow relations in the field of production and implementation of housing and communal services of an economic nature.

\section{The group of sources of shadow relations in the field of production and sale of housing and communal services of a state-management nature}

This category of shadow relations includes those that arose as a result of the use of imperfect mechanisms for carrying out socio-economic reforms and, consequently, errors in the management of socio-economic processes by the state. As a result, the following points became possible: the development of shadow privatization 
of housing and communal services; abuse of official position in making managerial decisions regarding housing and communal services; violation of legal rights and interests of citizens, due to abuse of official position in solving social protection issues of low-income citizens-consumers of housing and communal services; committing others, including financial and economic offenses in the investigated sphere.

It should be noted that the issue of the operational solution of problems in housing and communal services reform and the development of legislative and other normative legal acts regulating the relations in this area was entrusted in 1999 to the Interdepartmental Commission on Implementation of the Housing and Communal Services Reform. However, this commission has never conducted a meeting. There is no single state regulator of the municipal services market, and the functions on implementation of state policy in this area have been scattered among different central executive authorities (Ministry of Housing and Communal Services of Ukraine, State Housing and Municipal Inspection of Ukraine, State Inspection on Control at prices, the National Electricity Regulatory Commission of Ukraine, the Antimonopoly Committee of Ukraine). As a result, there was no single approach to the formation of tariffs on the utility market and the settlement of such services. In practice, this has led to large differences between the levels of tariffs for housing and communal services (housing and communal services certificate, 2016).

In all civilized countries, natural monopolies, such as communal enterprises, are the object of regulation of the state whose main task is to maximally protect the interests of the consumer by creating such legislative conditions for the work of these enterprises, which would maximally bring them closer to work in a competitive environment. Otherwise, the situation will be the same: at first, everything is plundering, and then the tariffs are raised to put everything in order. And since there are no conditions that would make it more effective to use investment resources, some of them are plundering again. This process tends to be infinite. Utility tariffs are rising almost every year inappropriately to the level of inflationary costs. Let's consider this question in more detail.

I. The group of sources of shadow relations in the sphere of production and sale of housing and communal services of a state-management nature:

1) the sources of shadow relations are associated with ineffective management of economic processes by public authorities.

The ways of such shadow manifestations are reflected in the adoption of organizational and legal decisions regarding the market transformation of socio-economic relations without the necessary adaptation to the economic and legal environment of the country and, as a result, produce negative shadow processes at the level of self-regulatory reproduction. The situation is aggravated by the lack of integrated control-information systems and the system of organizational, managerial, accounting, technological and legal institutions adapted to market relations.

In order to establish concrete methods and technology of shadow manifestations, it is enough to analyse the adopted regulatory legal acts regulating relations in the sphere of production and realization of housing and communal services, for their conformity to the economic and legal environment of the country, for this purpose it is necessary to conduct their economic legal examination and to use the classifier-matrix of economic and criminological monitoring of relations in the field of financial and economic turnover of things, rights, actions (Popovych, 2001).

Subjects of this category of shadow manifestations can be officials of legislative and executive power.

This category of methods of shadow manifestations is one of the most dangerous categories, because it causes the economic crisis, undermines the economic stability of the state, forms a negative attitude of the population towards the government and the state as a whole.

2) the sources of shadow relations are associated with ineffective administrative and municipal reforms, the incompleteness of the distribution of state and communal ownership, privatization processes in the communal sphere.

As a result of the reform of state power, according to the Law of Ukraine "On Local Self-Government in Ukraine" (1997) there is the creation of: systems of local self-government as public authorities of territorial communities and systems of bodies of state executive power submitted by local state administrations in accordance with the Law of Ukraine "On Local State Administrations" (1999).

However, the unclear legislative separation of their functions and powers, including in the sphere of production and sale of housing and communal services, became one of the sources of production of shadow relations in the investigated sphere.

Thus, because of the blurring of the delineation of powers and the different understanding of the limits of their own competence, is not clearly defined by the laws, separate bodies, as the practice of law enforcement shows, often conflict with each other. Particularly "problematic" is the relationship between regional state administrations and local self-government bodies at the level of villages, towns, and cities of district subordination and District Councils, as well as between regional state administrations and local governments of cities of regional subordination and Regional Councils (Komziuk, 2002). This is especially noticeable in branch laws, where the competence of local bodies of executive power and local self-government is often identical or defined in one and the same article. For example, according to the Law of Ukraine "On Housing and Communal Services" (The Law of Ukraine On Housing and Communal Services, 2004), local 
self-government bodies have the right to set prices/ tariffs, approve consumption and quality standards for housing and communal services, manage objects in the housing and communal services sector, located in the communal property of the respective territorial communities, etc., while in the Article 28 of the Law of Ukraine "On Local Self-Government in Ukraine" (1997) the powers of the executive self-regulatory bodies of village, town, and city councils include the establishment of tariffs for the payment of domestic, communal, transport and other services provided by enterprises and organizations of communal property of the certain territorial community; approval in the established order of these issues with enterprises, institutions and organizations that do not belong to communal property.

In accordance with Article 18 of the Law of Ukraine "On Local State Administrations" (1999), the authority to regulate prices and tariffs for the implementation of works and provision of housing and communal services by enterprises, as well as the definition and establishment of norms for their consumption, the exercise of control over their compliance, are owned by local state authorities.

Such legislative uncertainty and fuzziness have become a powerful source of shadow relations in the field of production and implementation of housing and communal services. As it enables the representatives of the above-mentioned bodies to influence the processes of shadow objects privatization of housing and communal services and makes it possible to use money from the privatization of communal objects improperly. 3) a group of sources related to ineffective control by the activity of producers and providers of housing and communal services.

Regarding control and oversight functions, which should be carried out by public organizations, they are still in declarative form in the sphere of production and sale of housing and communal services since no normative act has given them control and oversight functions in relation to quality control, quantity, prices/ tariffs for housing and communal services, did not establish an effective mechanism of their interaction with other bodies that have the rights to exercise control and supervision functions in the housing and communal sphere, subjects of management in the investigated sphere. Such legislative misregulation is also one of the sources of shadow relations in the housing and communal sector, as it promotes the shadowing of this segment of public relations.

4) the sources of shadow relations arising from offenses related to state registration, licensing and control functions of officials of state administration and local self-government bodies.

Such relations are the result of uncontrollability, irresponsibility of officials, cases of violations of the procedure for distributing budget funds, grants, licenses, etc., established by the current legislation, and the lack of reasonableness of organizational and legal decisions that led to the reverse effect, that is, the deepening of shadow relations and the creation of a new victimization, as an example to monitor the decision to replace the privileges for targeted subsidies for the payment of housing services.

5) a group of sources of shadow relations arising from administrative delinquencies.

This category of sources of shadow relations stems from administrative delicts and may not always have signs of economic activity. These are various administrative violations in the sphere of production and sale of housing and communal services, such as "Violation of the rules for the improvement of the territories of cities and other settlements" (Article 152 of Code of Ukraine on Administrative Offenses; "Violation of the legislation on protection consumer rights" (Article 156-1 Code of Ukraine on Administrative Offenses); "Violation of the order of formation and application of prices and tariffs" (Article 165-2 Code of Ukraine on Administrative Offenses); "Abuse of monopoly position in the market" (Article 166-1 Code of Ukraine on Administrative Offenses); "Issue and sales of products that do not meet the requirement standards" (Article 167 Code of Ukraine on Administrative Offenses); "Execution of works, providing services to citizens-consumers that do not meet the standard requirements, norms and rules" (Article 168-1 Code of Ukraine on Administrative Offenses), etc.

II. The group of sources of shadow relations in the sphere of production and sale of housing and communal services of an economic nature:

1) the sources of shadow relations arising from financial and economic violations in the sphere of production and sale of housing and communal services.

This category includes:

1. The sources of shadow relations arising from non-compliance with the methodology of reformed accounting, in accordance with the Law of Ukraine "On Accounting and Financial Reporting in Ukraine" (1999), accounting falsification.

2. The sources of shadow relations that arise as a result of the absence of legislative limitations on the marginal level of individual resource costs, technological costs and losses of water, heat at utility enterprises.

3. The sources of shadow relations that arise as a result of violation of tax laws. The scheme of evasion from taxes is given in Figure 1.

№ 1, 2 - Teploficator TOV purchased 2 bills with a discount of $50 \%$, the nominal value of bills -12 million hryvnias;

№ 3 - supply of heating was carried out by Prydniprovska TPP for the sum of 12 million hryvnias, including VAT -2 million hryvnias;

№ 4-TOV “Teploficator”, payments made for electricity received from Prydniprovska TPP are promissory notes 


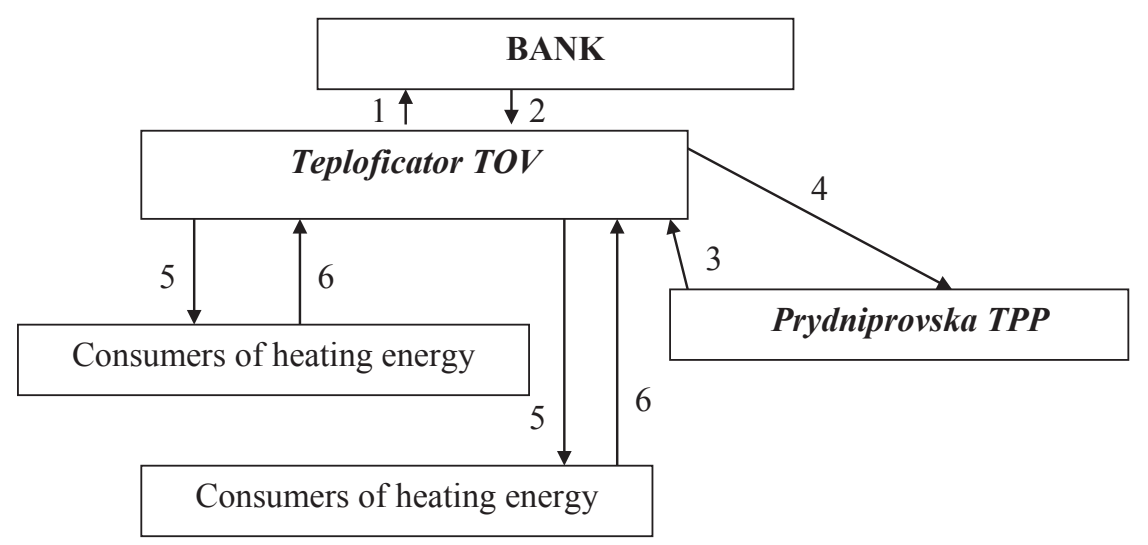

Figure 1. The scheme of tax evasion TOV SPBP "Teploficator" when calculating with the use of promissory notes

with a nominal value of 12 million hryvnias. Including the tax credit is 2 million hryvnias;

№ 5 - TOV “Teploficator” supplies heating energy to consumers for a total cost of 6 million hryvnias, including VAT - 1 million hryvnias;

№ 6 - consumers made calculations in cash.

As a result of the transaction with the use of bills of exchange, the tax liability of TOV "Teploficator" calculated in the amount of 1 million hryvnias, tax credit - 2 million hryvnias. The negative balance for reimbursement from the budget is 1 million hryvnias. Gross expenses amounted to 10 million hryvnias, gross income was 5 million hryvnias, and the loss from the transaction was 5 million hryvnias.

4. The sources of shadow relations that arise as a result of overstatement of material costs during business operations and partial understatement of profits.

5. The sources of shadow relations that arise as a result of the use of the cash method of tax payment for housing and communal services enterprises. There are no precise data for assessing the corresponding loss of enterprises with penalty tax and fines.

The most typical ways of shadow manifestations arising from financial and economic violations in the sphere of production and realization of housing and communal services are the following:

- failure by business entities to meet the requirements for the accounting of fixed assets, inventories, accounts receivable, liabilities, income, expenses, the formation of the production cost of utility services, income tax, etc.; - non-disclosure in the orders of the accounting policy of the housing and communal enterprise manufacturers working accounts in accordance with the orders of the Ministry of Finance of Ukraine, Guidelines for the application of the plan of accounting for assets, capital, liabilities and business operations of enterprises and organizations (1999), Provisions on documentary records in accounting (1995), Methodical Recommendations on the application of accounting registers (1998), the lack of principles and schemes for the production cost of services, the cost of production spine sales of services, operating expenses, income and financial operations, write-off inventory methods, procedures depreciation on fixed assets, the accounting features and low-value items, of primary documents and quality control of primary documents; absence of revolving balance sheets for reporting periods; - maintaining the Main Book without decoding debit accounts (only the numbers oflog-orders are indicated); - the inclusion into the structure of tariffs for housing and communal services amounts of bad debts and deductions to the reserve of doubtful debts, recognized fines, penalty taxes, expenses for the maintenance of objects of socio-cultural purposes, recreation centres, payment of travel vouchers, as well as related costs with financial results and source of payments for which there may be profit (bonuses by results of work for the whole year, material benefits for improvement);

- the lack of a clear distinction between financial and tax accounting;

- not creating and not charging a reserve of doubtful debts with significant amounts of current receivables and low solvency of consumers of public utilities;

- incorrect determination and display of the amount of deferred tax assets or liabilities in the balance sheet;

- unjustified overstatement or understatement of the currency of the balance sheet;

- incorrect accounting and writing-off expenses of accessary and assistant productions for the maintenance, operation and repair of fixed assets, for the performance of other services;

- the lack of managerial accounting and calculation of the cost of housing and communal services;

- the formation of tariffs is not based on technical and economic calculations, but by the cost method, that is, on the basis of actual expenses of past periods, the size of which is not sufficiently substantiated;

- abusive use of cash payments for subsidies for housing and communal services;

- overstatement of material expenses during business operations and partial understatement of received profit; 
- unjustified increase in tax credit; concealment of objects of taxation; understatement of taxation base.

2) the sources of shadow relations arising from the legitimate types of financial and economic activity of housing and communal enterprises related to pseudo-legal capital and document circulation.

This group includes sources of shadow relations, which stem from the legitimate types of financial and economic activity of housing and communal enterprises related to pseudo-legal capital and document circulation of housing and communal services producers.

Pseudo-legal civil turnover of housing and communal services producers is a set of economic operations of housing and communal services producers using legitimate civil and financial and economic instruments, but from unlawful motives, completely or partially unrecognized in the balance of business entities (for the purpose of theft, evasion from paying taxes, etc.) or fully accounted for, and inherently unlawful (pseudo-legal) shadow transactions.

The sources of shadow relations in this category include:

- operations for the sale of housing and communal services, within which the real price for housing and communal services may be overestimated or underestimated;

- operations for the sale of housing and communal services, within which a normative or over-the-year change in the quantity and quality of services may be issued (in the absence of a real decrease in real volumes or a decrease in the quality of products);

- operations for the sale of housing and communal services, within which separate services may not be delimited in the accounting of expenses not related to the ongoing repairs, the preparation of housing stock for work in winter, and the servicing of indoor water supply and sewerage networks.

The sale of housing and communal services is an independent and rather powerful source of shadow relations because in the absence of metering and regulating water and heat consumption, the producers of housing and communal services may establish overestimated consumption rates. For example, in Sumy and Kyiv, the daily rate of water consumption per capita is 300 litres. And nobody does not bother that an average person is physically unable to use such amount of water. Another example: the rate of gas consumption in Kyiv is almost 5 times higher than in Riga (Semchuk, 2016).

This category of shadow manifestations include:

- reduction in the quantity and quality of services provided when calculating tariffs according to full regulatory and over-regulatory indicators;

- the increase of own expenses due to inclusion in the cost of expenses on unscheduled repairs, excessive losses, unjustified transport losses, etc.;

- registration of only the size of the monthly fee for services without a list of services included in the tariff/ price and should be provided for the maintenance of houses and the total living space of the apartment. By the way, the composition of expenditures of housing enterprises, approved by the Cabinet of Ministers of Ukraine (Resolution of the Cabinet of Ministers of Ukraine, 1998), applies to residential premises and is taken into account in the calculation of rent, and a normative act that would determine the composition of expenses for the maintenance of non-residential premises is still absent, which also allows the providers services to resort to offenses, unjustifiably overestimate the price/tariff for services.

3) the sources of shadow relations arising from the production and sale of certain housing and communal services, for which the relevant organizational and legal requirements are established.

This group of sources of shadow relations should include those that are associated with failure of business entities to rules and regulations governing the process of production and implementation of housing and communal services.

The procedure for providing housing and communal services is regulated by the decree of the Cabinet of Ministers of Ukraine "On Approval of the Rules for the provision of services for centralized heating, supply of cold and hot water and drainage, and a standard contract for the provision of district heating services, supply of cold and hot water and drainage" (2005). This resolution deals with the procedure for providing services, their qualitative and quantitative indicators, which must meet the following criteria:

- cold water - sanitary and hygienic requirements regarding the quality of supplied water, as well as estimated water consumption at the point of disassembly (in an apartment or private house of the consumer); - hot water supply - sanitary and hygienic requirements regarding the quality and temperature of the heated water supplied, as well as the estimated flow of water at the point of disassembly (in an apartment or private home of the consumer);

- the heat supply (central heating) - the standard air temperature in the occupational environment of residential buildings in accordance with sanitary norms and rules provided that consumers take measures for their insulation and providers of housing maintenance services;

- drainage - sewage discharges with the observance of the sanitary-and-hygienic conditions of residential premises, basements of a residential building and adjoining territory.

Failure to comply with the abovementioned requirements in the housing and communal services sector and ineffective control by the authoritiessubjects of management in the housing and communal sphere makes it possible to violate the organizational and legal requirements that the production and 
implementation of housing and communal services should comply with.

It should also be noted that the requirements for quantitative and qualitative indicators of services should be determined by an agreement that should protect consumers from the arbitrariness of service providers, however, in most cases, it only contains the obligation of the residential utilities payment for consumers. The proposed Model Agreement on Provision of Water, Heat Supply and Wastewater Services to the population (1996) remained a declarative request of the Cabinet of Ministers of Ukraine since it was not taken as the basis by the service providers, and subsequently lost its validity (2005).

Such legal misregulation is a powerful source of shadow relations in the housing and utility sphere.

To this group of sources of shadow relations should be added also those that arise as a result of violations:

- Regulation on the system of maintenance, repair and reconstruction of residential buildings in the cities and villages of Ukraine (state document, 2004), which establishes terms, periodicity, norms for the implementation of current and capital repairs of residential buildings, as well as stipulates the implementation of works on technical maintenance and repair of the internal building sewer system;

- Typical rules of time and standards of service for workers and production personnel involved in the maintenance of housing stock (state document, 2004), which establishes the frequency and standards for cleaning the entrance of a residential building and adjoining territory;

- DBN 360-92 "Planning and development of urban and rural settlements", which defines the terms, periodicity and certain norms for the implementation of landscaping of the adjoining territory (arrangement of flower beds, planting trees, etc.) (state document, 2004);

- The procedure for calculation of housing organizations and enterprises of the Ministry of Energy for the servicing of internal-building power supply systems (Law of Ukraine, 2001);

- Licensing conditions for conducting economic activities for centralized water supply and drainage (Resolution of the National Commission, 2017).

\section{Conclusions}

The conducted study allowed us to formulate the author's definition of the concept of "shadow relations in the field of production and implementation of housing and communal services", carried out with the help of the developed in the theory of the de-shadowing of the economy (Popovych, 2001) methodology, generalized classification of sources of shadow relations in the field of production and implementation of housing and communal services, depending on the power of shadow capital turnover and public danger regarding the reproduction of shadow relations in this area. Such a classification is necessary for monitoring the financial and economic capital and document circulation in the sphere of production and realization of housing and communal services in order to determine the whole spectrum of sources of shadow relations - from socially neutral, socially positive, socially variable (disappearing) sources of the shadow economy informal sector, to socially-variable (newly formed), socially-negative and antisocial sources of the underground sector of the shadow economy.

Thus, socially-variable, newly formed sources of shadow relations should include groups of shadow relations defined in the second category - in paragraph 1 , paragraphs $2 ; 4 ; 6$; to socially-negative sources of shadow relations should include groups of shadow relations, defined in the first category - points $1 ; 4$, and in the second category - point 1 of subparagraphs $1 ; 2$; and paragraph 2 of sub-paragraph 2; to anti-social, we can include groups of sources of shadow relations, defined in the first category - paragraphs $2 ; 3 ; 5$ and in the second category - points $2 ; 3$.

The following groups of sources of shadow relations produce significant unlawful potential both in the sphere of production and realization of housing and communal services, as well as in the whole state regulation of financial and economic activity.

Due to the carried out research, it is possible to develop targeted and systematic measures that would be aimed at reducing the economic relations in the sphere of production and implementation of housing and communal services.

\section{References:}

Mandybura, V. O. (2001). Shljakhy podolannja ekonomichnoji zlochynnosti i korupciji v Ukrajini [Ways to overcome economic crime and corruption in Ukraine]. Ekonomichni zlochyny: poperedzhennja i borotjba z nymy. K.

Turchynov, O. (1995). Tinjova ekonomika: teoretychni osnovy doslidzhennja [Shadow economy: theoretical foundations of the study]. K.: Artek.

Popovych, V. M. (2001). Ekonomiko-kryminologhichna teorija detinizaciji ekonomiky: monoghrafija [Economic and criminological theory of unshadowing of the economy: monograph]. Irpin.

Dryghvalj, N. P. (2004). Orghanizacijno-pravovi osnovy detinizaciji vidnosyn u sferi oborotu objektiv intelektualjnoji vlasnosti: (PhD Thesis): 12.00.07 [Organizational and legal bases of unshadowing of relations in the field of turnover of intellectual property objects: (PhD Thesis). 12.00.07]. Irpin.

Ghroshovyk, Ju. Ja. (2003). Orghanizacijno-pravovi osnovy detinizaciji vidnosyn u sferi zovnishnjoekonomichnoji dijaljnosti: (PhD Thesis): 12.00.07. [Organizational and legal bases of unshadowing of relations in the field of foreign economic activity: (PhD Thesis). 12.00.07]. Irpin. 
U sichni-zhovtni zbytky pidpryjemstv ZhKKh sklaly 5,4 miljjarda. Retrieved from: http://bankruptcy-ua.com/ news/5819 (accessed 14.08.2018)

Informacijna dovidka Ministerstva reghionaljnogho rozvytku, budivnyctva ta zhytlovo-komunaljnogho ghospodarstva do pytannja „Shhodo prozorosti vstanovlennja cin na ghaz, taryfiv na gharjachu vodu, opalennja, elektroenerghiju, vplyvu jikh na platospromozhnistj naselennja ta ekonomiku krajiny". Retrieved from: http://www.ntser.gov.ua/.../Inform.dovidka\%20Minreghionu\%20d (accessed 14.08.2018 r)

Pro efektyvnistj vykonannja Zaghaljnoderzhavnoji proghramy „Pytna voda Ukrajiny” ta Zaghaljnoderzhavnoji proghramy reformuvannja ta rozvytku zhytlovo-komunaljnogho ghospodarstva. Retrieved from: http://www.dkrs.gov.ua/kru/uk/publish/article/95763; jsessionid=0E3C483387DFC3B69FBB4309D2A16753. app8:2 (accessed 14.08.2018)

Dovidka pro pidsumky roboty pidpryjemstv zhytlovo-komunaljnogho ghospodarstva za 2016 rik [Reference on the results of the operation of enterprises of housing and utilities infrastructure for 2016].

Pro misceve samovrjaduvannja v Ukrajini: Zakon Ukrajiny vid 21 travnja 1997 roku \# 280. Vidomosti Verkhovnoji Rady Ukrajiny. 1997. № 24. St. 170.

Pro miscevi derzhavni administraciji: Zakon Ukrajiny vid 9 kvitnja 1999 roku № 586-XIV. 1999. № 20-21. St. 190.

Komzjuk, A. T. (2002) Zakhody administratyvnogho prymusu v pravookhoronnij dijaljnosti miliciji: ponjattja, vydy ta orghanizacijno-pravovi pytannja realizaciji: monoghrafija [Measures of administrative coercion in police law enforcement activities: the concept, types, and organizational and legal issues of implementation: monograph]. Kharkiv: Vyd-vo Nac. un-tu vnutr. sprav.

Pro zhytlovo-komunaljni poslughy: Zakon Ukrajiny vid 24 chervnja 2004 roku № 1875-IV. Oficijnyj visnyk Ukrajiny. 2004. № 30. T. 1. St. 1985.

Pro bukhghaltersjkyj oblik ta finansovu zvitnistj v Ukrajini: Zakon Ukrajiny vid 16 lypnja 1999 roku № 996-XIV. Vidomosti Verkhovnoji Rady Ukrajiny. 1999. № 40. St. 365.

Pro zatverdzhennja Polozhenj (standartiv) bukhghaltersjkogho obliku: Nakaz Ministerstva finansiv Ukrajiny vid 31 bereznja 1999 roku № 87, iz zminamy, vnesenymy zghidno z nakazom Ministerstva finansiv Ukrajiny vid 25 lystopada 2002 roku № 989. Retrieved from: http://zakon.rada.dov.ua./cgi-bin/laws/main/cgi (accessed 14.08.2018)

Pro zatverdzhennja Polozhennja pro dokumentaljne zabezpechennja zapysiv u bukhghaltersjkomu obliku: Nakaz Ministerstva finansiv Ukrajiny vid 24 travnja 1995 roku \# 88. Retrieved from: http://zakon.rada.dov.ua./cgi-bin/ laws/main/cgi (accessed 14.08.2018)

Pro vdoskonalennja systemy derzhavnogho reghuljuvannja rozmiru kvartyrnoji platy ta platy za utrymannja budynkiv i prybudynkovykh terytorij: Postanova Kabinetu Ministriv Ukrajiny vid 22 chervnja 1998 roku № 939. Oficijnyj visnyk Ukrajiny, № 30.

Semchuk, Gh. M. (2016) Suchasnyj stan i problemy reformuvannja pidpryjemstv vodoprovidno-kanalizacijnogho ghospodarstva Ukrajiny [Current state and problems of reforming the enterprises of water and sewage utilities in Ukraine]. Informacijnyj bjuletenj Ministerstva reghionaljnogho rozvytku, budivnyctva ta zhytlovo-komunaljnogho ghospodarstva Ukrajiny, 5-6, 35-41.

Pro vdoskonalennja systemy derzhavnogho reghuljuvannja rozmiru kvartyrnoji platy ta platy za utrymannja budynkiv i prybudynkovykh terytorij: Postanova Kabinetu Ministriv Ukrajiny vid 22 chervnja 1998 roku № 939. Oficijnyj visnyk Ukrajiny, № 30.

Pro zatverdzhennja Pravyl nadannja poslugh z centralizovanogho opalennja, postachannja kholodnoji ta gharjachoji vodyi vodovidvedennja ta typovogho doghovoru pro nadannja poslugh z centralizovanogho opalennja, postachannja kholodnoji ta gharjachoji vody i vodovidvedennja: postanova Kabinetu Ministriv Ukrajiny vid 21.07.2005 \# 630. Retrieved from: http://zakon3.rada.gov.ua/laws/show/630-2005-\%D0\%BF (accessed 14.08.2018)

Pro zminu rozmiriv vidshkoduvannja naselennjam vartosti zhytlovo-komunaljnykh poslugh: Postanova Kabinetu Ministriv Ukrajiny vid 10 sichnja 1996 roku № 39. Retrieved from: http://zakon.rada.dov.ua/cgi-bin/laws/main/ cgi (accessed 14.08.2018)

Pro vyznannja takymy, shho vtratyly chynnistj, dejakykh postanov Kabinetu Ministriv Ukrajiny: Postanova Kabinetu Ministriv Ukrajiny vid 13.04.2005 № 290. Retrieved from: http://zakon5.rada.gov.ua/laws/show/ 290-2005-\%D0\%BF (accessed 14.08.2018)

Lyst vid 13 ljutogho 2004 r. \# 4/1-159 Derzhavnogho komitetu Ukrajiny z pytanj zhytlovo-komunaljnogho ghospodarstva. Retrieved from: http://zakon.rada.dov.ua/cgi-bin /laws main/cgi (accessed 14.08.2018)

Pro orghany samoorghanizaciji naselennja: Zakon Ukrajiny vid 11 lypnja 2001 roku № 2625-III. Vidomosti Verkhovnoji Rady Ukrajiny. 2001. № 48. St. 254.

Pro zatverdzhennja Licenzijnykh umov provadzhennja ghospodarsjkoji dijaljnosti z centralizovanogho vodopostachannja ta vodovidvedennja: Postanova Nacionaljnoji komisiji, shho zdijsnjuje derzhavne reghuljuvannja u sferakh energhetyky ta komunaljnykh poslugh vid 22.03.2017 № 307. Retrieved from: http://zakon5.rada.gov.ua/ laws/show/v0307874-17 (accessed 14.08.2018) 